\title{
The Role of Human Capital in the Education Sector in Efforts to Create Reliable Organizational Human Resources
}

\author{
Suryono Efendi \\ Universitas Nasional, Jakarta, Indonesia \\ Email: suryono.efendi@yahoo.com
}

\begin{abstract}
Knowledge, skills and talents that may be utilized to provide professional services are human capital. The firm has a collective ability for the creation of ideas, innovations and appropriate solutions to help the company accomplish its business goals. The ability of human capital is for individuals to win the world's competition to offer employees with more financial value. Thus, this study is intended to establish the function of human capital in creating trustworthy human resources within the education sector. A qualitative technique is used in this study by gathering literature-based research data sources. The results demonstrate that the function of human capital is crucial in the education sector, since human capital provides a strong basis for the advancement of the educational world and for the creation of a new order that is essential in today's progressive world.
\end{abstract}

Keywords: Human Capital, Education, Human Resources.

\section{A. INTRODUCTION}

Talks on the subject of investment of human capital, which might contribute to economic progress, have been place since Adam Smith (1776), Heinrich Von Thunen (1875), and other scientists of the classical economy, before 19th century. In the end, Schultz (1961) then showed that the development of the education sector with human capital as its core focus had contributed directly to the economic growth through increasing the skills and production capabilities of the workforce owned by the company. These findings and perspectives have stimulated the interest of several scholars to research the economic value of education (Blundell et al., 1999). We will agree that the higher the level of education of a person, the more excellent the opportunity to get a decent and good job, that is the general answer in every era of social life.

Historically, education was viewed as a type of social service that needed to be supplied to the community; in this context, education services were viewed as part of public services or as services provided by a country to its citizens, which did not appear to have a direct influence at the time. For the community's economy, educational development is not attractive to be a theme of attention, and its position does not get exciting attention in the development steps (Irianto, 2017). However, in the end, it was realized that education has a significant influence on the economic growth of a nation.

Human beings are intrinsically valuable, and capital is intrinsically valuable. Thus, Human Capital is the process of transforming individuals into capital or 
intangible assets, as the majority of companies rely on human capacity to innovate, develop brands, and adapt to changing markets in order to grow (Barro, 2001). Human capital is a term that refers to a society's collection of valuable human talents and knowledge. Indeed, human capital is a long-term investment in human resource development with the goal of increasing productivity, although one that is less evident in the short term (instant). The value of human capital is that the knowledge contained within human resources serves as the foundation for boosting production. The term "human capital" was coined in response to a change in the function of human resources (Woodhall, 1987).

Human capital arises from the idea that humans are intangible assets that have many advantages, namely human ability when used and distributed, will not decrease but increase both for the individual concerned and for the organization, humans can transform data into meaningful information, humans can share intelligence with other parties (Sukoco \& Prameswari, 2017).

Human capital is not positioning humans as capital like machines, so it seems humans are the same as machines, as the previous human capital theory. However, as this idea gained traction, it became clear that human capital might assist decisionmakers in concentrating on human development by emphasizing investment in education (including training) as a means of improving the quality of organizations as part of nation-building (Lengkong, 2018). Handling human resources as human capital shows that the returns from non-physical investments are much higher than investments in the form of physical development (Siregar, 2014)

Education itself is a tool to develop the economy and not just grow the economy (Sudarsana, 2016). A technical-economic function from the individual to the larger level is one of the five purposes of education in contemporary education management. The technical-economic role of education results in its contribution to economic growth. For example, education can help humans acquire the knowledge and skills needed to survive and compete in an increasingly competitive economic life (Purwanto, 2006). One of the characteristics of developed countries is the high level of education and mastery of technology. Therefore, education is highly emphasized to improve human resources' quality and quality, such as skills, skills, and knowledge training about the business world to create competitive, competent, creative human resources. , broad-minded and have high integrity required by various business sectors, both industrial and other sectors (Idris, 2016)

Education is the most critical investment tool for humans as capital in competing in the global era (Efendi, 2020). Formal education alone cannot guarantee that humans can work, but supporting facilities or institutions are also needed, such as job training institutions outside of school. Even college graduates are not entirely equipped for the workforce when they graduate and must be integrated into their workplaces via official and informal training programs. Therefore, a person's expertise and skills in facing labour competition are greatly influenced by how high, and the breadth of education each individual has (Sudarsana, 2016). 
Therefore, efforts and programs are needed to create superior and high-quality human resources to face international competition. The world of work is very demanding to obtain highly varied human resources. With education, a person's potential will be able to be well directed so that it can make an efficient human being. Education also makes humans more knowledgeable and have better abilities.

\section{B. METHOD}

This study uses a qualitative design by conducting an epistemological literature study by examining the role of human capital in education. The use of qualitative designs supported by the literature allows how to get that knowledge or, in other words, how is the process that provides knowledge in the form of knowledge to be obtained through procedures, what things are considered to get proper knowledge, what is called truth, what are the criteria for truth and how technique, what it means to help acquire knowledge called knowledge (Anggito \& Setiawan, 2018).

\section{RESULT AND DISCUSSION}

\section{Human Capital}

Human resources are the essential assets in the company because, through the skills, expertise and knowledge possessed by humans in the company or organization, they will be able to bring the company to have the ability to survive and even win every competition. Competitive advantage is a company characteristic that distinguishes a company from other companies, in the form of advantages and uniqueness that are different from other companies or even competitors will bring an organization/company to grow and develop to face all kinds of challenges and even be able to take advantage of opportunities that arise exists (Dwi Atmanti, 2005).

Human Capital is competence, knowledge, social and personality attributes, including creativity, embodied in working to generate economic value. The critical factor in production is people, and people are the only organizational success factor that is not traded as an organization's trading commodity (Barro, 2001). So far, the measurement of corporate performance is only measured through financial achievements, even though these measurements do not reflect the actual competitiveness of the organization and have not been able to predict future organizational performance. Intellectual capital and innovation potential are the longterm keys to the "health" of the organization, and that human or "human capital" is the primary source of both assets (Anatan, 2006).

According to Adam Smith (1776), human capital is in the form of abilities and skills obtained through education, self-study, learning while working, and that requires costs incurred by the person concerned. The acquisition of skills and abilities will result in a very high rate of return to one's income. Based on the Human Capital approach, there is a linear relationship between Education Investment and "Higher Productivity \& Higher Earning". As the primary capital invested, humans will produce educated people who are productive and increase income as a result of the 
quality of work displayed. In the company/organization, human capital is a factor of human resources in the organization, forming a series of combinations of intelligence, skills, and expertise that provide organizational characteristics/character (Hidayat, 2013).

Human capital theory is a school of thought that holds that individuals are a type of capital or capital goods, alongside other forms of capital such as land, buildings, and machinery. On a macro (nation) level, human capital may be described as the sum total of a country's citizens' knowledge, skills, and intellect.

Theodore W Schultz reintroduced Human Capital (Human Capital) through his speech entitled "Investment in Human Capital" before American economists in 1960, then published in the journal American Economic Review in March 1961. Previously, economists only knew physical capital in tools, machines, and other production equipment, which is suspected of contributing to economic growth and development. Schultz's concept of human capital is that the process of obtaining knowledge and skills via education is not a wasted activity but rather a kind of investment in Human Resources (HR). Education, as a way of fostering human traits, directly contributes to the increase of state income by improving the workforce's skills and production capacities (Schultz, 1961).

Human capital is one of the essential concepts in the world today. This concept is very influential, especially, though perhaps not exclusively, in the economic field. In this framework, human capital is considered instrumental in the economic growth and prosperity of a country. Therefore, countries that want to enjoy economic growth and prosperity must seriously consider and develop their human capital. Human capital development is a form of investment (investing in people) and is an unavoidable demand of the modern economy (Schultz, 1981).

A person or employee who has the ability and skills in an organization is precious to the company; with a high commitment, they will exert all their energy and ability to advance the organization in achieving its goals. When employees with high competence increase, productivity will also increase through effective and efficient organizational activities. Thus the company has more value than their competitors. The company's increasing ability will impact corporate growth and achievement of goals; every organizational activity is managed optimally, including improving service to customers (Putri, 2013).

Organizational success is a product of the competence of the organization's people; the relationship between people and performance will benefit all stakeholders. Employees who have high competence are highly valued by the company and must be given trust, treated reasonably to provide an increased commitment to the company; in turn, organizational performance will also increase.

\section{The Role of Human Capital in the Education Sector}

Various understandings expressed by some experts about the meaning of education. According to Charters \& Good (1945) in "Dictionary of Education", it is mentioned that education is the art, practice, or profession of teaching, the systematic 
learning of concepts and techniques of instruction, as well as student management and direction; the phrase education is frequently repeated. In line with the definition of education according to Richey in his book "Planning for Teaching" an introduction to education it is explained that: the term education refers to the wide role of preserving and enhancing a community's life, particularly in terms of educating new members (the younger generation) about their obligations and responsibilities in society. (Richey, 1979). Another opinion was also expressed by Suhartono (2008) that: education is all learning activities that take place throughout the ages in all situations of life activities.

Thus, it can be understood that the three of them have different explanations for the definition of education. So, Carter and Suhartono's description is more in line with ongoing education. Namely, education is a learning activity that continues throughout the ages. With a structured system, education can produce guided, educated students to have art based on the learning gained during education. This is supported by the National Education System Law No. 20 of 2013. In addition, it is supported according to Arba'iyah's opinion that the educational process can take place at any time, anywhere and anytime, with no age limit. This statement follows the phrase: "Education is life long, Life Long Education is in Unility All of Life" (Arba'iyah, 2012).

Education, according to the SIKDIKNAS law number 20 of 2003, is a deliberate and planned effort to create a learning environment and learning process in which students actively develop their potential for religious-spiritual strength, self-control, personality, intelligence, noble character, and skills. He is required by himself, by society, by the nation, and by the state.

Education is a critical component of the human life cycle, from conception to death (long life education). Education, conceptually, is a deliberate and planned effort to educate the nation's energy and develop the Indonesian people as a whole in order for them to develop into human beings who believe and fear God Almighty, have a noble character, are healthy, knowledgeable, capable, creative, and independent, and who become democratic and responsible citizens. Education is the process through which instructors convey knowledge (science, technology, and art) to their students. Additionally, education is a tool for transforming our thinking from conventional to scientific (modern) thinking (Arbai'iyah, 2012).

In the explanation above, it is clear that educational planning needs to be considered so that every person has and produces values that build and change for the nation and state's progress. To get a quality education, one must have a conscious effort both within the person (students) and schools (school institutions) or teachers. Another thing that is needed is a planned education with the preparations owned. The acquisition of education is human beings with noble character (moral) and religious humans (religious).

According to Ki Hadjar Dewantara, the concept of education in Indonesia is a). Indonesian people who are virtuous are those who have inner strength and character. Education is directed to improve the image of humans in Indonesia to be firm in taking 
sides with the values of truth. b). Humans in Indonesia who are advanced in their minds are cognitively intelligent (knows a lot and knows a lot). Their intelligence frees them from ignorance and duping in various types and forms: because of colonial engineering in the form of indoctrination. Humans in Indonesia who have progressed at the physical or body level are those who are not only physically healthy but moreover have the proper knowledge about the functions of their bodies and understand these functions to free themselves from all impulses towards criminal acts.

Meanwhile, John Dewey believes education is one with growing; it has no end beyond itself, so it will never be permanent but always evolutionary. In addition to always being an ongoing process, the participatory education model rests on democratic values, participation, pluralism and liberalism.

The two concepts above do have different images. This can be seen from the two figures giving the idea of education. These other concepts have a background in understanding the culture of each country. If Ki Hadjar Dewantara focuses on the context of education in Indonesia, it is not wrong. Likewise, John Dewey explains the concept of education following the cultural context of western countries. However, it should be noted that the existence of parallels and alignments of thought is both directing humans in a virtuous direction and through a process of growth step by step. So this is in line with the concept of the education law in Indonesia no. 20 of 2003. In addition to the above images, it is also necessary to pay attention to the differences in location (village, ethnicity, city, culture) of each region in Indonesia. It aims to carry out learning following the context of areas in Indonesia.

From the explanation above, it has been discussed that Human Capital is an essential part of the continuity of education. Every school certainly has efforts and efforts so that education can run well. Likewise, it has been discussed in the concept of education and Human Capital that there must be individuals (schools, educational institutions) who manage to run capital according to the object. Thus, there is a relationship between education and Human Capital, namely the passage of education in a good direction, and it is influenced by human capital (human resources). Good human resources can support the continuity of education. Developments and changes in education can be seen if education can be realized correctly and according to the objectives (vision and mission).

Academic life is considered prosperous if its resources can support educational activities and activities on an ongoing basis. Education that has good resources can produce good quality education. This means that prosperity (availability) of facilities, both advanced facilities and infrastructure, is due to well-managed human resources.

In the 21st century, Human Capital has experienced a very rapid increase in direction. This is due to the understanding of human resources that support and make an excellent contribution to education development. The effect of this understanding is increasingly improving the quality and attention to existing education. It gives exceptional value to use its existence in education, social, cultural and political with high human ability. Human knowledge can compete and even survive to win the surrounding competitions. This can be done by showing creativity, innovation and 
breakthroughs in carrying out responsibilities, for example, in schools (Sugiono et al., 2019).

Thus, it can be seen that the brief history of HC arises from the thought that humans have values that can be relied on in all aspects of human life. This ability possessed by humans continues to be developed to support and develop education in schools and even outside schools (companies). This clearly shows that humans continue to experience the development of knowledge following their times, experiencing changes following learning values that continue to be in demand and cultivated. Old to the new order in today's post-modern era.

Education requires human capital because education is the most necessary capital investment to solve the global issues today. Many studies have shown that in America, even if direct and indirect cost of schooling is deducted, university and higher education significant enhance the income of a person. Even after adjusting to the fact that persons are more likely and more educated to have higher IQs. Over a hundred countries with various cultures and economic systems have now received similar evidence over several years. More educated people's salaries almost usually exceed average, although in poorer nations they generally make more significant improvements.

Of course, not the only method to invest in human capital is formal schooling. Workers are also taught and trained beyond school, particularly at work. Even university students who leave school are not entirely ready for the job market and must be adapted through official and informal training programs. Therefore, how high and broad the education of each individual is, depends to a person's knowledge and talents in dealing with work rivalry. Efforts and initiatives are thus needed to build outstanding and high-quality human resources to compete internationally. In the world of work, very diverse human resources are required.

\section{CONCLUSION}

Based on the description above, it can be concluded that education and HC have an inseparable relationship in running the existing system. Quality education is education that gives complete trust to HC following the field they are involved in. Through this field, they can develop the economy and improve the quality of education. The relationship between education and HC continues to be developed by placing it following the roles and responsibilities given. So we need to realize that the importance of the part of Human Capital in Education is because human capital to stay alive is determined by capital in the form of material. Still, education is needed as a bridge to broad-minded people.

\section{REFERENCES}

1. Anatan, L. (2006). Manajemen Modal Intelektual: Strategi Memaksimalkan Nilai Modal Intelekstual dalam Technology Driven Business. Jurnal Manajemen Maranatha, 5(2), 46-56. 
2. Anggito, A., \& Setiawan, J. (2018). Metodologi penelitian kualitatif. Jejak Publisher.

3. Arba'iyah, Y. (2012). Long Life Education_Belajar Tanpa Batas. PEDAGOGIA: Jurnal Pendidikan, 1, 111-130.

4. Barro, R. J. (2001). Human Capital and Growth. American Economic Review, 91(2), 12-17.

5. Blundell, R., Dearden, L., Meghir, C., \& Sianesi, B. (1999). Human Capital Investment: The Returns From Education and Training to The Individual, The Firm and The Economy. Fiscal Studies, 20(1), 1-23.

6. Charters, W. W., \& Good, C. V. (1945). The Dictionary of Education. The Phi Delta Kappan, 27(1), 5-7.

7. Dwi Atmanti, H. (2005). Investasi Sumber Daya Manusia Melalui Pendidikan. Jurnal Dinamika Pembangunan (JDP), 2(Nomor 1), 30-39.

8. Efendi, S., Sugiono, E., Guritno, E., Sufyati, \& Hendryadi. (2020). Building innovation and competitiveness for low technology manufacturing SMEs through imitating capability and learning: The case of Indonesia. Cogent Social Sciences, 6(1), 1803515.

9. Hidayat, C. (2013). Analisis Model Pengukuran Human Capital Dalam Organisasi. Binus Business Review, 4(2), 879-885.

10. Idris, H. A. (2016). Pengantar Ekonomi Sumber Daya Manusia. Deepublish.

11. Irianto, H. A. (2017). Pendidikan Sebagai Investasi Dalam Pembangunan Suatu Bangsa. Kencana.

12. Lengkong, Y. P. (2018). Pengaruh Human Capital dan Relation Customer Capital Terhadap Business Performance di PT. Karunia Lestari (Doctoral dissertation, UPN Veteran Jawa Timur).

13. Purwanto, N. A. (2006). Kontribusi Pendidikan Bagi Pembangunan Ekonomi Negara. Jurnal Manajemen Pendidikan UNY, 114456.

14. Putri, N. K. (2013). Peran Human Capital terhadap Kesuksesan Organisasi: Karyawan Adalah Investasi. Jurnal Administrasi Kebijakan Kesehatan, 11(2), 93-97.

15. Richey, R. W. (1979). Planning For TeachingaAn Introduction to Education 6th ed. Mcgraw hill book company.

16. Schultz, T. W. (1961). Investment In Human Capital. The American Economic Review, 51(1), 1-17.

17. Schultz, T. W. (1981). Investing in people. University of California Press.

18. Siregar, Z. M. E. (2014). Strategi Human Capital Bank Mandiri. ECOBISMA (Jurnal Ekonomi, Bisnis dan Manajemen), 1(2), 11-18.

19. Sudarsana, I. K. (2016). Peningkatan Mutu Pendidikan Luar Sekolah Dalam Upaya pembangunan Sumber Daya Manusia. Jurnal Penjaminan Mutu, 1(1), 1-14.

20. Sugiono, E., Efendi, S., \& Sumardi, R. (2019). Peran Inovasi Sebagai Mediasi Hubungan Antara Modal Intelektual Dengan Keunggulan Bersaing UKM. Jurnal Riset Manajemen dan Bisnis (JRMB) Fakultas Ekonomi UNIAT, 4(S1), 543-556.

21. Suhartono, S. (2008). Wawasan Pendidikan: Sebuah Pengantar Pendidikan. Yogyakarta: Ar-Ruzz Media. 
22. Sukoco, I., \& Prameswari, D. (2017). Human Capital Approach to Increasing Productivity of Human Resources Management. AdBispreneur: Jurnal Pemikiran dan Penelitian Administrasi Bisnis dan Kewirausahaan, 2(1).

23. Woodhall, M. (1987). Human Capital Concepts. In Economics of Education (pp. 2124). Pergamon. 